\title{
Metal Biosorption by Surface-Layer Proteins from Bacillus Species
}

\author{
Allievi, Mariana Claudia, Sabbione Florencia, Prado-Acosta Mariano, Palomino María Mercedes, \\ Ruzal Sandra M.*, and Sanchez-Rivas Carmen
}

Universidad de Buenos Aires, Facultad Ciencias Exactas y Naturales, Departamento de Química Biológica, Cdad, Universitaria Pabellón II, $4^{\circ}$ piso, C1428EGA, Buenos Aires. Argentina

Received: September 30, 2010 / Revised: October 27, 2010 / Accepted: November 11, 2010

\begin{abstract}
Bacillus species have been involved in metal association as biosorbents, but there is not a clear understanding of this chelating property. In order to evaluate this metal chelating capacity, cultures and spores from Grampositive bacteria of species either able or unable to produce surface layer proteins (S-layers) were analyzed for their capacity of copper biosorption. Only those endowed of S-layers, like Bacillus sphaericus and $B$. thuringiensis, showed a significant biosorption capacity. This capacity (nearly $50 \%$ ) was retained after heating of cultures, thus supporting that structural elements of the envelopes are responsible for such activity. Purified Slayers from two Bacillus sphaericus strains had the ability to biosorb copper. Copper biosorption parameters were determined for strain $B$. sphaericus 2362, and after analyses by means of the Langmuir model, the affinity and capacity were shown to be comparable to other bacterial biosorbents. A competitive effect of $\mathrm{Ca}^{2+}$ and $\mathrm{Zn}^{2+}$, but not of $\mathrm{Cd}^{2+}$, was also observed, thus indicating that other cations may be biosorbed by this protein. Spores that have been shown to be proficient for copper biosorption were further analyzed for the presence of $S$ layer content. The retention of $S$-layers by these spores was clearly observed, and after extensive treatment to eliminate the S-layers, the biosorption capacity of these spores was significantly reduced. For the first time, a direct correlation between S-layer protein content and metal biosorption capacity is shown. This capacity is linked to the retention of S-layer proteins attached to Bacillus spores and cells.
\end{abstract}

Keywords: Metal biosorption, S-layer, Bacillus, spores

Metals are essential elements, but at high concentrations they become toxic to living organisms, including soil

* Corresponding author

Phone: +54 11457633 42; Fax: +54 11457633 42;

E-mail: sandra@qb.fcen.uba.ar microorganisms. Bioremediation is an important tool for environmental remediation of heavy metals [1]. Biological methods to remove metals from liquid effluents present many potential advantages. The use of bacterial and fungal biomass as biosorbents should be of special interest to industries in undeveloped countries, where pollution generators cannot afford to install costly high-performance treatment facilities. These biosorbents are an alternative to conventional chemical methods [9].

The members of the family Bacillaceae present potential characteristics for metal biosorption owing to their multiple additional envelopes and composition of their spores (coat or exosporium). Their cell wall may be overlaid by a number of surface structures that can interact with metal ions, such as the exopolysaccharide (EPS) and the paracrystalline surface layer (S-layer). Regarding the EPS, its biosorption capacity has been established for Paenibacillus polymyxa P13 [22], whereas the S-layer is present in species of Archaea and Bacteria and constitutes the outermost structure of the cell. The latter is essentially composed of proteins arranged in a crystalline multilayer array formed by the self-assembly of monomer subunits on the surfaces of the cells. The S-layer covers the whole surface of the cell and could represent $15 \%$ of total proteins [25]. These proteins are amenable to introduce surface motifs as metal-binding domains and immunological motifs $[20,16]$. Some S-layer proteins are glycosylated and/or phosphorylated. Amine, carboxyl, and hydroxyl groups are also aligned on the surface and maintained by hydrophobic, electrostatic, and Van der Waals forces. The S-layer is not only a protective coat, but is also involved in cell adhesion, surface recognition, and pathogenicity [7, 14, 23]. In fact, a Bacillus sphaericus strain (JG-A12) isolated from an uranium mining waste pile is able to accumulate high amounts of toxic metals such as $\mathrm{U}, \mathrm{Cu}$, $\mathrm{Pb}, \mathrm{Al}$, and $\mathrm{Cd}$ as well as precious metals; this capacity has been attributed to the highly ordered paracrystalline proteinaceous surface layer that envelopes the cell [21]. In addition, the genus Bacillus has the ability to form spores 
that resist chemical and physical constraints and survive in harsh places. Most of the resistance properties of these spores have been in part attributable to the multiple-layer structure (the coat) surrounding the spore in a protective and flexible shield. Basic biochemical features of the coat have shown that it is composed largely of proteins with smaller amounts of carbohydrates and lipids. This multilayered structure is composed of up to 25 proteins, often highly cross-linked, which grants the spore resistance to UV light, treatments with solvents such as chloroform, or access to lysozyme. Coat proteins are especially rich in the amino acids tyrosine and cysteine [6], which have a great potential capacity for metal biosorption, owing to the presence of sulfide bonds. Moreover, the CotA protein displays similarities with multicopper oxidases [12] since it contains, in particular, four copper-binding sites. Selenska-Pobell et al. [26] reported that spores from several Bacillus isolates (B. megaterium, B. sphaericus, B. cereus) biosorb $\mathrm{U}, \mathrm{Cu}, \mathrm{Pb}$, $\mathrm{U}$, and Al. On the other hand, Chung et al. [3] reported data on metal-binding characteristics of some metal ligands related to spores, and He and Tebo [11] reported that spores of the marine Bacillus sp. SG-1 are capable of oxidizing $\mathrm{Mn}$ (II) and $\mathrm{Co}$ (II) and exhibit a high affinity for $\mathrm{Cu}(\mathrm{II})$. These authors argued that in Bacillus sp. SG-1, the surface charge is primarily associated with the outermost layer of the spore, the exosporium, and that this would be involved in the metal association. Several reports have indicated that enzyme-binding metals are present in this structure $[5,8]$. To date there is no clear understanding of how this metal interaction has been obtained. In our laboratory, we have studied the S-layer proteins of Bacillus species to try to solve the lack of information concerning metal-bacteria interaction.

In order to evaluate the metal chelating capacity, using copper as a model, we analyzed Gram-positive bacteria, spores, or cultures of species either able or unable to produce S-layers. To address this fact, different treatments of cells and spores were tested, including purification of Slayer proteins. We describe here the first report for a direct correlation between S-layer content and metal biosorption capacity.

\section{Materials ANd Methods}

\section{Microorganisms and Media}

All the Bacillus strains used belong to the collection of our laboratory. B. subtilis, B. sphaericus, and B. thuringiensis (listed in Table 1) were provided originally by the Pasteur Institute. The CP1 strain is a crystal negative ErmR mutant obtained by introducing the pTV1ts plasmid containing the transposon Tn917::ermR [24] in the $B$. thuringiensis var. israelensis 1884 strain. Spores were obtained after culturing the different Bacillus strains for $2-3$ days at $32^{\circ} \mathrm{C}$ on solid Schaeffer or Yousten media. Plates were scrapped with $1 \mathrm{M} \mathrm{NaCl}$, washed four times in bi-distilled water, and freeze-stored at $-20^{\circ} \mathrm{C}$ [4].

Lactobacillus acidophilus ATCC4356 belongs to the Collection of our laboratory and was provided originally by the CERELACONICET Institute (Tucumán, Argentina). The L. acidophilus strain was cultured in MRS medium at $32^{\circ} \mathrm{C}$.

\section{S-Layer Preparations}

For S-layer preparations, Bacillus sphaericus 2362 and Kellen Q strains were grown in LB medium in order to avoid sporulation. Lactobacillus acidophilus was cultured in MRS medium. Cells from 100-ml exponential cultures were harvested and washed once with PBS. The S-layer proteins were extracted by using $6 \mathrm{M} \mathrm{LiCl}$, followed by centrifugation $(15,000 \times g$ for $15 \mathrm{~min})$. The pellets were extracted again with $10 \mathrm{ml}$ of the same reagent and incubated for $30 \mathrm{~min}$ at room temperature. The supernatants were collected and dialyzed against distilled water overnight at $4^{\circ} \mathrm{C}$, allowing the S-layer proteins to precipitate. After centrifugation $(10,000 \times g$ for $20 \mathrm{~min}$.), the pellets containing the S-layers were suspended in dionized water and stored at $-20^{\circ} \mathrm{C}$.

\section{Copper Absorption Experiments}

Analytical-grade $\mathrm{CuSO}_{4} \cdot 5 \mathrm{H}_{2} \mathrm{O}$ (Sigma) was prepared in dionized water as $1,000 \mathrm{ppm}$ stock solutions.

Freeze-dried spores were weighed, and aliquots of 0.1 to $1 \mathrm{mg}$ were suspended in dionized water containing the metal solutions $\left(\mathrm{Cu}^{2+}\right.$ at 100 or $200 \mathrm{ppm}$ ) at optimized conditions of $\mathrm{pH}$ and temperature $(\mathrm{pH}$ 5 and $25^{\circ} \mathrm{C}$ ) [22]. After biosorption reached equilibrium, spores

Table 1. Copper absorption experiments with spores and cultures from different Bacillus strains.

\begin{tabular}{lcc}
\hline Strains & $\begin{array}{c}\text { Biosorption capacity of Spores } \\
\left(\mathrm{ppm} \mathrm{of} \mathrm{Cu}^{2+}\right)\end{array}$ & $\begin{array}{c}\text { Biosorption capacity of Cultures } \\
\left(\mathrm{ppm} \mathrm{of} \mathrm{Cu}^{2+}\right)^{\mathrm{a}}\end{array}$ \\
\hline Bacillus subtilis YB886 & $8.9 \pm 0.1$ & $9.8 \pm 4.8$ \\
Bacillus subtilis 168 & $10.3 \pm 1.1$ & $9.7 \pm 0.7$ \\
Bacillus sphaericus 2362 & $12.5 \pm 0.8$ & $36.3 \pm 1.7$ \\
Bacillus sphaericus 1593 & $22.7 \pm 1.7$ & $7.4 \pm 2.2$ \\
Bacillus thuringiensis var. israelensis 1884 & $15.8 \pm 1.5$ & $22.9 \pm 1.3$ \\
Bacillus thuringiensis var. israelensis 1884 Cry-4 (CP1) & $18.8 \pm 0.2$ & $31.9 \pm 2.7$ \\
\hline
\end{tabular}

Experiments were performed with either spores or whole cells as described in Materials and Methods. Assays were performed with 1 mg of spores and $100 \mathrm{ppm}$ of copper for $2 \mathrm{~h}$.

${ }^{\mathrm{a}}$ For cultures (whole cells), $200 \mathrm{ppm}$ of copper was used and incubated with $1 \mathrm{mg}$ of whole cells for $16 \mathrm{~h}$. The ppm of $\mathrm{Cu}^{2+}$ biosorbed was calculated and the results shown are the average of four independent experiments. 
were directly removed by centrifugation $(20,000 \times g)$. The residual unabsorbed metal in the supernatant was determined by the BCA method [2]. The metal biosorbed was determined as follows: $\left(\mathrm{C}_{\mathrm{i}}-\right.$ $C_{f}$ ), where $C_{i}$ and $C_{f}$ are the initial and equilibrium concentration of metal in the solution (ppm), being $\mathrm{C}_{\mathrm{i}} 100\left(100 \mathrm{ppm} \mathrm{Cu}^{2+}\right)$. Results shown in the data tables represent one of at least two or four independent experiments.

When whole cells were used, cultures exponentially grown in LB or MRS media (according to the strain) were collected, the $\mathrm{OD}_{600 \mathrm{~nm}}$ was determined, and cultures were centrifuged and concentrated. Aliquots of 0.1 to $1 \mathrm{mg}$ bacteria suspended in deionized water were confronted with $200 \mathrm{ppm}$ copper and was biosorption determined as indicated for spores. The dry weights were determined from lyophilized samples of each culture and dry weight $/ \mathrm{OD}_{600 \mathrm{~nm}}$ calculated for all strains. When S-layers were used, 0.1 to $1 \mathrm{mg}$ protein was used for each experiment.

The metal uptake (q) was determined as follows: $q=V\left(C_{f}-C_{i}\right) / W$, where $\mathrm{V}$ is the volume of solution in the tube, $\mathrm{W}$ is the mass weight of the adsorbent (S-layers, spores, or cells) $(\mathrm{g})$, and $\mathrm{C}_{\mathrm{i}}$ and $\mathrm{C}_{\mathrm{f}}$ are the initial and equilibrium concentrations of the metal in the solution (ppm), respectively. The influence of other metal ions at different concentrations $(25,50,100,150$, and $200 \mathrm{ppm})$ was also assayed on copper (100 ppm) biosorption. Analytical-grade $\mathrm{CdSO}_{4}, \mathrm{CaCl}_{2}$, and $\mathrm{ZnSO}_{4}$ (Sigma) were prepared in dionized water as $1,000 \mathrm{ppm}$ stock solutions.

\section{Calculation of Biosorption Isotherm Parameters}

The isotherm data were adjusted to the linear form of the Langmuir equation biosorption model: $\mathrm{C}_{\mathrm{f}} / \mathrm{q}_{\max }=\left(1 / \mathrm{q}_{\max }\right) \mathrm{b}+\mathrm{C}_{\mathrm{f}} / \mathrm{q}_{\max }$, where $\mathrm{q}$ is the metal uptake by the biosorbent $(\mathrm{mg} / \mathrm{g}), \mathrm{C}_{\mathrm{f}}$ is the equilibrium concentration of the metal in the solution (ppm), and $\mathrm{b}$ and $\mathrm{q}_{\max }$ are empirical constants of the Langmuir isotherm, representing affinity and maximum uptake capacity, respectively.

\section{S-Layer Analysis in Spores by Western Blot}

Proteins were analyzed by $10 \%$ SDS-PAGE in a Mini-Protean II Electrophoresis Cell (BioRad). Gels were stained with Coomassie Brilliant Blue. For Western blot analysis, gels were electrotransferred to membranes with a parablot PVDF according to the manufacturer's instructions (Macherey-Nagel, Germany), soaked with a polyclonal antiS-layer antibody diluted 1:2,000 and revealed with HRP-conjugated anti-rabbit IgG (Santa Cruz Biotechnology). Chemiluminescence was detected using ECL (Sigma).

\section{RESULTS}

\section{Metal Biosorption by Whole Cells and Spores}

Several Bacillus species known to either produce S-layers or not were chosen, and their spores and cultures were subjected to a biosorption assay. Copper was used as a metal model, which is an essential element, but at high concentrations it becomes toxic to living organisms, including soil microorganisms. Only those species known to produce S-layers, such as Bacillus sphaericus and Bacillus thuringiensis, showed a high absorption capacity (Table 1). Spores of these same species were also good candidates for biosorption.

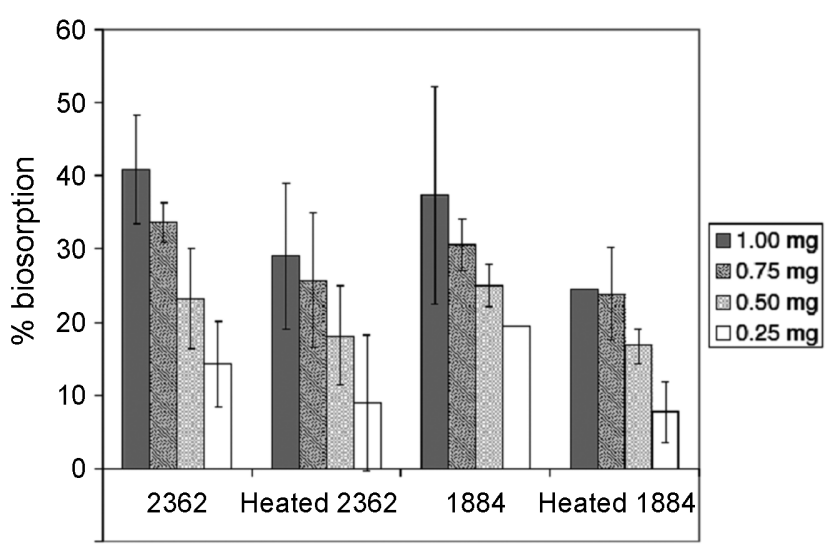

Fig. 1. Copper absorption of whole Bacillus cells either heattreated or not.

Exponential cultures of B. sphaericus 2362 and B. thuringiensis var israelensis 1884 were collected and concentrated. They were either heated $\left(10 \mathrm{~min}\right.$ at $70^{\circ} \mathrm{C}$ ) or not and 0.25 to $1 \mathrm{mg}$ of whole cells was subjected to the assay reported in Table 1 . The percentages of biosorption were calculated and reported and error bars were calculated from four different experiments.

In order to further investigate this behavior, different bacterial inputs of these two species were analyzed for copper biosorption. In addition, the same cultures were heat-treated and analyzed. As shown in Fig. 1, a direct correlation between bacterial input and \% biosorption was observed with both strains: both retained $40 \%$ copper per milligram of bacteria. The heat-treated cells were still able to retain copper, thus discarding that active transport or enzymatic activity would be required and indicating rather that the envelope structure is the one responsible for such effect. A similar behavior regarding the biosorption of metals and its resistance to heating has been reported for several B. sphaericus strains [29].

\section{Characteristics of Culture Biosorption}

The metal uptake isotherms for $\mathrm{Cu}^{2+}$ plotted against the final metal concentration $\left(\mathrm{C}_{\mathrm{f}}\right)$ in aqueous solutions are shown in Fig. 2A. Data were analyzed using the classical Langmuir biosorption model. This model assumes that biosorption occurs in a monolayer, that all biosorption sites are identical, and that no changes in adsorption free energy are observed at all sites. Biosorption parameters obtained after linearization of the Langmuir model (Fig. 2B) showed that copper biosorption mediated by B. sphaericus 2362 is in agreement with this model. Parameters calculated of this biosorption model are maximum uptake capacity $\left(\mathrm{q}_{\max }\right)$ of $\mathrm{Cu}(\mathrm{II})$ of $47.17 \mathrm{mg} / \mathrm{g}$ and affinity (b) constant of $0.0063 \mathrm{l} / \mathrm{mg}$, with a correlation coefficient $\left(\mathrm{R}^{2}\right)$ of 0.9976 .

This affinity value is in the same order of magnitude as the affinity of $\mathrm{Cu}(\mathrm{II})$ determined for EPS [22], and the biosorption capacity is within the range described for other biomasses [17, 28]. 

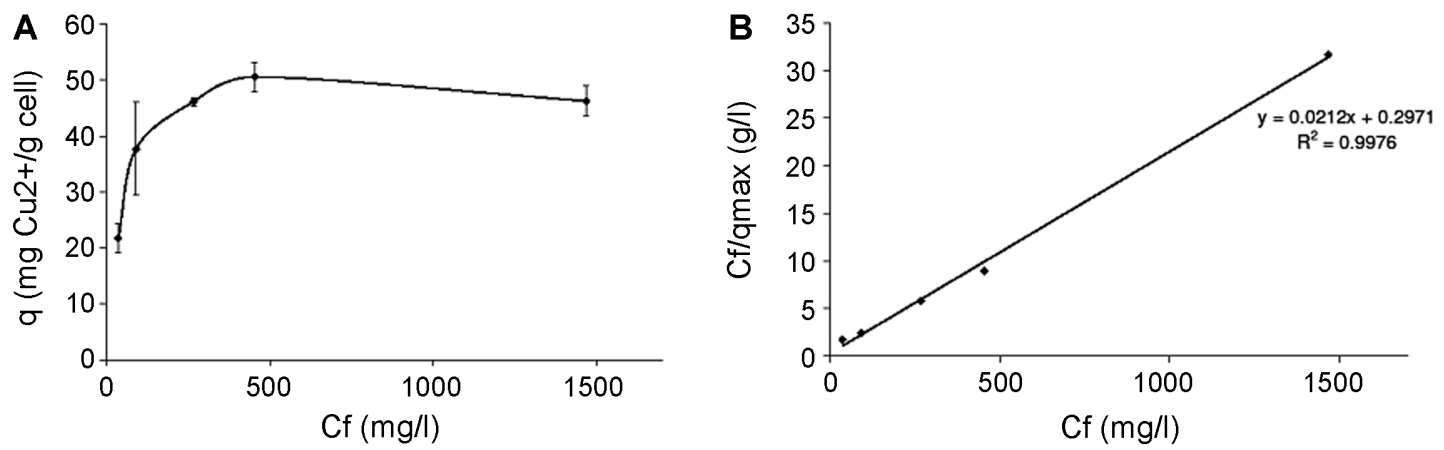

Fig. 2. Biosorption isotherm of $\mathrm{Cu}^{2+}$ by B. sphaericus 2362 .

A. $\mathrm{q}$ (number of occupied sites: $\mathrm{mg} \mathrm{Cu}{ }^{2+}$ biosorbed/g cellular dry weight) vs. $\mathrm{C}_{\mathrm{f}}$ (copper equilibrium concentration): (A) experimental data, (B) Langmuir model linearization.

\section{Effects of Other Ions}

Since it has been shown that cultures of Bacillus strains obtained from contaminated environments biosorb several toxic metals [26], we wanted to investigate whether cultures of Bacillus sphaericus 2362 endowed of the S-layer biosorbed other metals. For this purpose, copper biosorption experiments were carried out in the presence of a second cation at concentrations from 50 to $200 \mathrm{ppm}$. For each experiment the coprecipitation due to the presence of both salts was estimated in parallel and shown to be negligible. $\mathrm{Ca}^{2+}$ and $\mathrm{Zn}^{2+}$, but not $\mathrm{Cd}^{2+}$, competed with $\mathrm{Cu}^{2+}$, since at $50 \mathrm{ppm}, 20 \%$ of inhibition effect was observed (Fig. 3), indicating that these cultures bearing the S-layer can be efficient in retaining cations other than copper.

\section{Metal Biosorption of S-Layers}

In order to investigate whether any type of S-layer was important in this biosorption capacity, Bacillus sphaericus (strains Kellen Q and 2362) and Lactobacillus acidophilus (ATCC4356) were chosen and their S-layers purified. The S-layer proteins extracted from the two B. sphaericus

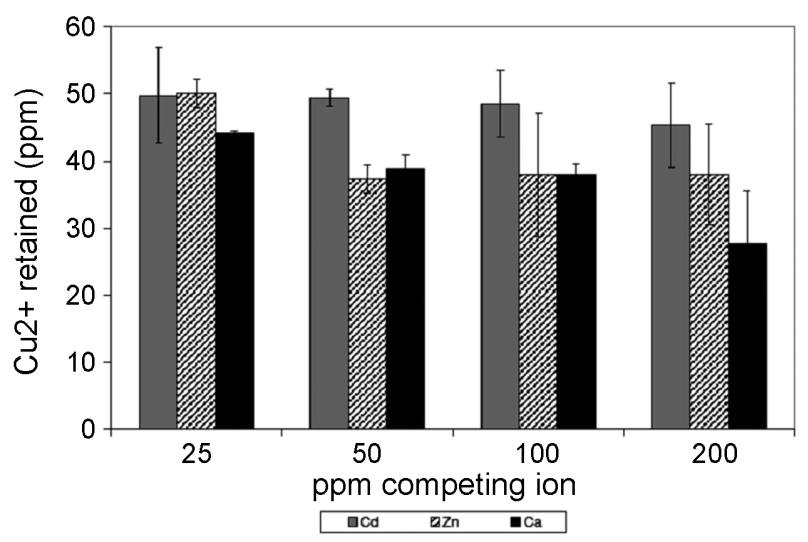

Fig. 3. Effects of other ions.

The competitive effect was tested by pairing $\mathrm{Cu}^{2+}$ with each ion. The presence of increasing ion concentrations was evaluated using 100 ppm initial $\mathrm{Cu}^{2+}$ concentration and $4 \mathrm{mg}$ cells $/ \mathrm{ml}$. strains, but not that of L. acidophilus, presented a significant copper biosorption capacity (Table 2), and was also observed with whole cells. In order to further evaluate the biosorption capacity of the S-layer per se, purified S-layers from $B$. sphaericus 2362 were obtained. A titration with different inputs of S-layer protein was performed and biosorption was shown to be proportional to the protein present, retaining $85 \mathrm{ppm}$ of $\mathrm{Cu}^{2+}$ per milligram of S-layer (Fig. 4).

\section{S-Layers in Spores}

In the assay shown in Table 1, we confirmed that spores from strains that synthesized S-layers during the vegetative growth were also efficient in the copper biosorption assay. Since several reports have previously indicated that the Slayer protein remains firmly attached to spore preparations from S-layer-producing bacteria such as B. anthracis [30], we explored the possibility that the biosortion capacity of spores was in part influenced by the S-layer protein content of the spores. To address this fact, spores from $B$. sphaericus 2362 were subjected to different washing protocols prior to the copper biosorption assay. One of these protocols included an EDTA treatment known to

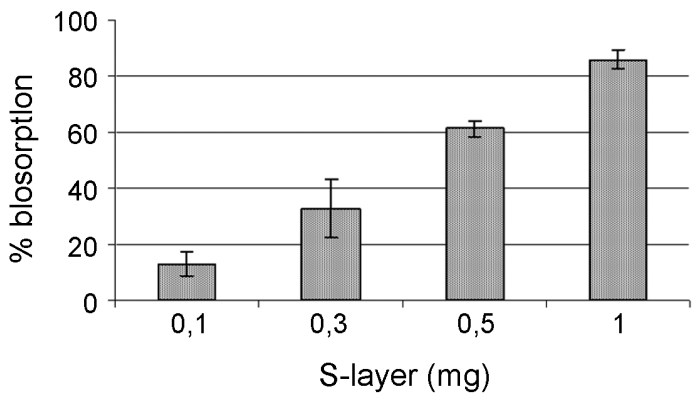

Fig. 4. Biosorption capacity of the S-layer from B. sphaericus 2362.

Different concentrations of purified S-layer from B. sphaericus 2362 (from 0.1 to $1 \mathrm{mg}$ ) were mixed with $100 \mathrm{ppm}$ of copper solution, and the percentage of copper retained calculated as indicated in Table 1. 
Table 2. Copper biosorption experiments with whole cells or S-layer.

\begin{tabular}{|c|c|c|c|}
\hline \multirow[b]{2}{*}{ Strains } & \multirow[b]{2}{*}{ Biosorbent condition } & \multicolumn{2}{|c|}{ Assay } \\
\hline & & $0.1 \mathrm{mg}^{\mathrm{a}}$ & $1 \mathrm{mg}^{\mathrm{a}}$ \\
\hline \multirow[t]{2}{*}{ B. sphaericus Kellen Q } & Whole cells & $15.8 \pm 1.5$ & $24.1 \pm 1.5$ \\
\hline & S-layer & $16.2 \pm 1.7$ & $93.0 \pm 2.5$ \\
\hline \multirow[t]{2}{*}{ Lb. acidophilus ATCC4356 } & Whole cells & $<1$ & $<1$ \\
\hline & S-layer & $0.7 \pm 0.5$ & N.D \\
\hline \multirow[t]{2}{*}{ B. sphaericus 2362} & Whole cells & $7.1 \pm 1.8^{*}$ & $36.3 \pm 1.7^{*}$ \\
\hline & S-layer & $12.8 \pm 4.3^{*}$ & $85.9 \pm 3.2 *$ \\
\hline
\end{tabular}

The ppm of biosorbed $\mathrm{Cu}^{2+}$ was calculated as described in Materials and Methods. ${ }^{*}$ In these experiments, $200 \mathrm{ppm}$ of copper was added. Results shown are the average of two independent experiments.

${ }^{\mathrm{a}}$ The assays were performed with two concentrations $(0.1 \mathrm{mg}$ and $1 \mathrm{mg})$ of whole cells or S-layer protein.

disperse S-layers from the envelope of Archeae. Spores retained important quantities of S-layers, as revealed by Western blot, but after intensive washing, this protein disappeared (compare lanes 2 and 4 in Fig. 5A). When these spore preparations were subjected to the biosorption assay shown in Table 1, sample 2 retained much more copper than samples 3 and 4 , which presented scarce or null S-layer (Fig. 5B). It should be remarked that sample 4 showed values similar to those of $B$. subtilis strains devoid of S-layer (8.8 compared with 8.9 for B. subtilis YB886 in Table 1). This background biosorption value could be attributed to spore envelope constituents that are negatively charged and thus bind metal cations.

\section{DisCUSSION}

In this paper, we showed that Bacillus strain cultures producing S-layers presented a very high capacity to biosorb copper. This property was observed with cultures

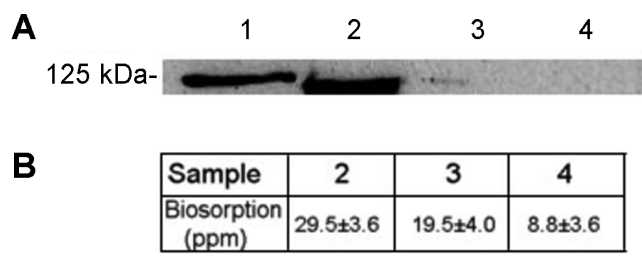

Fig. 5. Presence of S-layer in spore preparations and biosorption capacity.

B. sphaericus 2362 strain was used. Spores from 3-day culture on Yousten plates were scrapped and washed with $10 \mathrm{ml}$ of $1 \mathrm{M} \mathrm{NaCl}$ and subjected to different cleaning protocols: sample 2 was washed once in deionized water; sample 3 was washed five times in deionized water; sample 4 was washed once in deionized water, once in $0.5 \mathrm{mM}$ EDTA, and four times in deionized water. All spores were lyophilized and further analyzed for Slayer content and biosorption capacity. (A) SDS-PAGE Western blot analysis with anti-S-layer was carried out as described in Materials and Methods. Lane 1: control of S-layer pure protein $(10 \mu \mathrm{g})$; lanes 2 to 4 : washed spore samples 2, 3, and 4 (64 $\mu \mathrm{g}$ spores ). (B) Biosorption of samples 2, 3, and 4 was determined, as in Table 1 with $1 \mathrm{mg}$ of spores and $200 \mathrm{ppm}$ of $\mathrm{Cu}^{2+}$. and spore preparations. It is remarkable that heated cultures or spores were able to retain this capacity. The heating step presented the advantage to inactivate proteases, always present in Bacillus cultures, allowing the protection of the S-layer protein. Biosorption behaved according to the classical Langmuir model (Fig. 2).

Regarding the S-layer, it is important to remark that it represents $15 \%$ to $20 \%$ of the total proteins of the bacteria. Although several articles have postulated the importance of the presence of the S-layer from Bacillus strains in metal biosorption [21], ours is the first report of a direct correlation between S-layer content and biosorption. We clearly showed its relevance with the purified S-layer proteins from several B. sphaericus strains (Table 2 and Fig. 4). Biosorption of copper onto the investigated Slayers was not specific, since other metals competed well (Fig. 3). Regarding the use of spores as relevant for the remediation process, we presented evidence for the first time showing that this capacity is linked to the retention of S-layer proteins attached to these spores, both in $B$. sphaericus (Fig. 5) and in B. thuringiensis (data not shown). The spore coats or the exosporium are not as good biosorbents as the S-layer, since spores from $B$. subtilis devoid of exosporium behaved similarly to extensively cleaned spores from B. sphaericus endowed of exosporium (compare Table 1 and Fig. 5B lane 4), discarding the importance of these structures.

Both the phosphorylated amino acids and the carbohydrates from the glycosylated protein have been suspected as possible capture sites of the S-layers. Merroun et al. [18] attributed metal absorption to the phosphorylation content of the S-layer from B. sphaericus JG-A12. We performed in silico analysis of the S-layers from $L$. acidophilus (not performant for biosorption) and B. sphaericus [15, 27] for their content of phosphorylation sites (threonine and serine) and found that both presented a similar high content $(21 \%$ and $18 \%)$, thus suggesting that an additional characteristic of the S-layers was necessary. We rather suspected that glycosylation may be involved in such 
property since only the S-layer from $B$. sphaericus, but not that of L. acidophilus, was able to biosorb and be glycosylated.

Regarding the yield of S-layers, it is our experience that exponential cultures of B. sphaericus produced more attached-S-layers than early-stationary-phase ones, explaining the great differences obtained between each batch of the same strain (see error bars in Fig. 1). Either cultures or purified S-layers were efficient biosorbents.

In addition, environmental variations have been shown to influence the composition and localization (attached, free, or inside spores) of the S-layers [10], and even the expression of different slp genes present in the strains $[13,19]$. The optimization of the conditions for S-layer production attached to the cells or spores and the biosorption capacity (strain selection, growth phase, media, stress input, and metal assayed) will be the aim of our future investigations.

\section{Acknowledgements}

We thank Dr. Lynn Lewis for kindly providing us with the antibody against S-layers from $B$. sphaericus strains. This work was supported by research grants from the Consejo Nacional de Investigaciones Científicas y Técnicas from Argentina (CONICET). M.C.A., M.P.A., and M.M.P. are $\mathrm{PhD}$ fellows from CONICET. C.S.R. and S.M.R. are career investigators from CONICET.

\section{REFERENCES}

1. Andreazza, R., S. Pieniz, L. Wolf, M. K. Lee, F. A. Camargo, and B. C. Okeke. 2010. Characterization of copper bioreduction and biosorption by a highly copper resistant bacterium isolated from copper-contaminated vineyard soil. Sci. Total Environ. 408: $1501-1507$.

2. Brenner, A. J. and E. D. Harris. 1995. A quantitative test for copper using bicinchoninic acid. Anal. Biochem. 226: 80-84. [Published erratum appears in Anal. Biochem. 1995; 230: 360.]

3. Chung, L., K. S. Rajan, E. Merdinger, and N. Grecz. 1971. Coordinative binding of divalent cations with ligands related to bacterial spores. Equilibrium studies. Biophys. J. 11: 469-482.

4. Cucchi, A. and C. Sanchez Rivas. 1994. Sensitivity of growing cells and spores of Bacillus thuringiensis var. israelensis and Bacillus sphaericus to osmotic variations. Curr. Microbiol. 28: 123-127.

5. Dick, G. J., J. W. Torpey, T. J. Beveridge, and B. M. Tebo. 2008. Direct identification of a bacterial manganese(II) oxidase, the multicopper oxidase MnxG from spores of several different marine Bacillus species. Appl. Environ. Microbiol. 74: 1527-1534.

6. Driks, A. 1999. Bacillus subtilis spore coat. Microbiol. Mol. Biol. Rev. 63: 1-20.

7. Engelhardt, H. 2007. Are S-layers exoskeletons? The basic function of protein surface layers revisited. J. Struct. Biol. 160: 115-124.
8. Francis, C. A., K. L. Casciotti, and B. M. Tebo. 2002. Localization of $\mathrm{Mn}$ (II)-oxidizing activity and the putative multicopper oxidase, $\mathrm{MnxG}$, to the exosporium of the marine Bacillus sp. strain SG-1. Arch. Microbiol. 178: 450-456.

9. Garavaglia, L., S. B. Cerdeira, and D. L. Vullo. 2010. Chromium (VI) biotransformation by beta- and gamma-Proteobacteria from natural polluted environments: A combined biological and chemical treatment for industrial wastes. J. Hazard Mater. 175: 104-110.

10. Guo, G., L. Zhang, Z. Zhou, Q. Ma, J. Liu, C. Zhu, L. Zhu, Z. Yu, and M. Sun. 2008. A new group of parasporal inclusions encoded by the S-layer gene of Bacillus thuringiensis. FEMS Microbiol. Lett. 282: 1-7.

11. He, L. M. and B. M. Tebo. 1998. Surface charge properties of and $\mathrm{Cu}(\mathrm{II})$ adsorption by spores of the marine Bacillus sp. strain SG-1. Appl. Environ. Microbiol. 64: 1123-1129.

12. Hullo, M. F., I. Moszer, A. Danchin, and I. Martin-Verstraete. 2001. CotA of Bacillus subtilis is a copper-dependent laccase. $J$. Bacteriol. 183: 5426-5430.

13. Jakava-Viljanen, M., S. Avall-Jaaskelainen, P. Messner, U. B. Sleytr, and A. Palva. 2002. Isolation of three new surface layer protein genes (slp) from Lactobacillus brevis ATCC 14869 and characterization of the change in their expression under aerated and anaerobic conditions. J. Bacteriol. 184: 6786-6795.

14. Kern, J. W. and O. Schneewind. 2008. BslA, a pXO1-encoded adhesin of Bacillus anthracis. Mol. Microbiol. 68: 504-515.

15. Lewis, L. O., A. A. Yousten, and R. G. Murray. 1987. Characterization of the surface protein layers of the mosquitopathogenic strains of Bacillus sphaericus. J. Bacteriol. 169: 72-79.

16. Liu, M., S. Li, S. Hu, C. Zhao, D. Bi, and M. Sun. 2008. Display of avian influenza virus nucleoprotein on Bacillus thuringiensis cell surface using CTC as a fusion partner. Appl. Microbiol. Biotechnol. 78: 669-676.

17. Lo, W., L. M. Ng, H. Chua, P. H. Yu, S. N. Sin, and P. K. Wong. 2003. Biosorption and desorption of copper(II) ions by Bacillus sp. Appl. Biochem. Biotechnol. 105-108: 581-591.

18. Merroun, M. L., J. Raff, A. Rossberg, C. Hennig, T. Reich, and S. Selenska-Pobell. 2005. Complexation of uranium by cells and S-layer sheets of Bacillus sphaericus JG-A12. Appl. Environ. Microbiol. 71: 5532-5543.

19. Mignot, T., S. Mesnage, E. Couture-Tosi, M. Mock, and A. Fouet. 2002. Developmental switch of S-layer protein synthesis in Bacillus anthracis. Mol. Microbiol. 43: 1615-1627.

20. Pollmann, K. and S. Matys. 2007. Construction of an S-layer protein exhibiting modified self-assembling properties and enhanced metal binding capacities. Appl. Microbiol. Biotechnol. 75: $1079-1085$.

21. Pollmann, K., J. Raff, M. Merroun, K. Fahmy, and S. SelenskaPobell. 2006. Metal binding by bacteria from uranium mining waste piles and its technological applications. Biotechnol. Adv. 24: $58-68$.

22. Prado Acosta, M., E. Valdman, F. Battaglini, S. Leite, and S. M. Ruzal. 2005. Biosorption of copper by Paenibacillus polymyxa cells and their exopolysaccharide. World J. Microbiol. Biotechnol. 21: 1157-1163.

23. Prado Acosta, M., S. M. Ruzal, M. C. Allievi, M. M. Palomino, and C. Sanchez Rivas. 2010. Synergistic effects of the Lactobacillus acidophilus surface layer and nisin on bacterial growth. Appl. Environ. Microbiol. 76: 974-977. 
24. Sandman, K., R. Losick, and P. Youngman. 1987. Genetic analysis of Bacillus subtilis spo mutations generated by Tn917mediated insertional mutagenesis. Genetics 117: 603-617.

25. Sára, M. and U. B. Sleytr. 2000. S-Layer proteins. J. Bacteriol. 182: 859-868.

26. Selenska-Pobell, S., P. Panak, V. Miteva, I. Boudakov, G. Bernhard, and H. Nitsche. 1999. Selective accumulation of heavy metals by three indigenous Bacillus strains. $B$ cereus, $B$ megaterium from drain waters of a uranium waste pile. FEMS Microbiol. Ecol. 29: 59-67.

27. Smit, E., F. Oling, R. Demel, B. Martinez, and P. H. Pouwels. 2001. The S-layer protein of Lactobacillus acidophilus ATCC 4356: Identification and characterisation of domains responsible for S-protein assembly and cell wall binding. J. Mol. Biol. 305: 245-257.

28. Tsekova, K., D. Todorova, V. Dencheva, and S. Ganeva. 2010. Biosorption of copper(II) and cadmium(II) from aqueous solutions by free and immobilized biomass of Aspergillus niger. Bioresour. Technol. 101: 1727-1731.

29. Velasquez, L. and J. Dussan. 2009. Biosorption and bioaccumulation of heavy metals on dead and living biomass of Bacillus sphaericus. J. Hazard. Mater. 167: 713-716.

30. Williams, D. D. and C. L. Turnbough. 2004. Surface layer protein EA1 is not a component of Bacillus anthracis spores but is a persistent contaminant in spore preparations. J. Bacteriol. 186: $566-569$. 